\title{
Time-Dependent Neutronic Analysis of a Power-Flattened Gas Cooled Accelerator Driven System Fuelled with Thorium, Uranium, Plutonium, and Curium Dioxides TRISO Particles
}

\author{
Gizem Bakır, ${ }^{1}$ Gamze Genç, ${ }^{2}$ and Hüseyin Yapıcı ${ }^{2}$ \\ ${ }^{1}$ Cumhuriyet Üniversitesi Teknoloji Fakültesi, 58140 Sivas, Turkey \\ ${ }^{2}$ Erciyes Üniversitesi Mühendislik Fakültesi, 38039 Kayseri, Turkey \\ Correspondence should be addressed to Hüseyin Yapıc1; yapici@erciyes.edu.tr
}

Received 14 July 2016; Accepted 3 August 2016

Academic Editor: Eugenijus Ušpuras

Copyright ( 2016 Gizem Bakır et al. This is an open access article distributed under the Creative Commons Attribution License, which permits unrestricted use, distribution, and reproduction in any medium, provided the original work is properly cited.

\begin{abstract}
This study presents the power flattening and time-dependent neutronic analysis of a conceptual helium gas cooled Accelerator Driven System (ADS) loaded with TRISO (tristructural-isotropic) fuel particles. Target material is lead-bismuth eutectic (LBE). $\mathrm{ThO}_{2}, \mathrm{UO}_{2}, \mathrm{PuO}_{2}$, and $\mathrm{CmO}_{2}$ TRISO particles are used as fuel. $\mathrm{PuO}_{2}$ and $\mathrm{CmO}_{2}$ fuels are extracted from PWR-MOX spent fuel. Subcritical core is radially divided into 10 equidistant subzones in order to flatten the power produced in the core. Tens of thousands of these TRISO fuel particles are embedded in the carbon matrix fuel pebbles as five different cases. The high-energy Monte Carlo code MCNPX 2.7 with the LA150 library is used for the neutronic calculations. Time-dependent burnup calculations are carried out for thermal fission power $\left(P_{\text {th }}\right)$ of 1000 MW using the BURN card. The energy gain of the ADS is in the range of 99.98-148.64 at the beginning of a cycle. Furthermore, the peak-to-average fission power density ratio is obtained between 1.021 and 1.029 at the beginning of the cycle. These ratios show a good quasi-uniform power density for each case. Furthermore, up to $155.1 \mathrm{~g}{ }^{233} \mathrm{U}$ and $103.6 \mathrm{~g}{ }^{239} \mathrm{Pu}$ per day can be produced. The considered system has a high neutronic capability in terms of energy multiplication, fissile breeding, and spent fuel transmutation with thorium utilization.
\end{abstract}

\section{Introduction}

Currently, Light Water Reactors (LWRs) and Canada Deuterium Uranium (CANDU) reactors, which use uranium sources, generate the most of nuclear electricity. Commercial nuclear reactors produce highly radioactive materials as highlevel wastes. They mainly contain transuranic isotopes $(\mathrm{Np}$, $\mathrm{Pu}, \mathrm{Am}$, and $\mathrm{Cm})$ and long-lived fission products. Most countries prefer to bury these wastes in concrete containers in the sea bed. On the other hand, transmutation of these wastes by driving high-energetic neutron and/or proton source is an improved approach. Lawrence [1] is the first to transmute thorium to ${ }^{233} \mathrm{U}$ by releasing fast neutrons from a spallation target bombarded with high-energetic protons. The potentials of nuclear fuel transmutation in various fusion-fission hybrid reactors fuelled with several spent fuels extracted from conventional nuclear reactors are investigated in our previous studies (Yapıcı et al. [2, 3]).
Many studies on transmutation of nuclear waste and fissile fuel breeding in ADSs have been performed in recent years. Barros et al. investigated potentials of fissile breeding and transmutation for a lead cooled ADS loaded with thorium and reprocessed fuel $[4,5]$. Their results show that the use of $\mathrm{ThO}_{2}$ and reprocessed fuel combination enabled uranium $\left({ }^{233} \mathrm{U}\right)$ production without the initial ${ }^{233} \mathrm{U}$ enrichment. $\mathrm{Vu}$ and Kitada [6] propose a conceptual design of ADS utilizing thorium fuel and reprocessed fuel for transmutation of nuclear waste and production of energy. Abánades and PérezNavarro [7] examine the transmutation of nuclear waste in a gas cooled ADS moderated with graphite. TRISO is formed from nuclear wastes and they show that $95 \%$ of plutonium can be transmuted (except ${ }^{242} \mathrm{Pu}$ ). García et al. [8] evaluate the real number of pebbles fitting in a cylindrical ADS core in detail. The transmutation of MA in a lead-bismuth cooled ADS is analyzed by Takizuka et al. [9] and Tsujimoto et al. [10]. Takizuka et al. indicate that the waste transmutation 
of $250 \mathrm{~kg} /$ year is obtained by $80 \%$ plant factor. According to Tsujimoto et al., their ADS design productively transmutes and burns the MA when the effective neutron multiplication factor is 0.97. A uranium spallation target in an ADS loaded with MA is considered by Ismailov et al. [11]. Lead-bismuth $(\mathrm{PbBi})$ target and uranium target are compared in their study and results show that the limited geometrical size of uranium target has better neutron multiplication than that of leadbismuth $(\mathrm{PbBi})$ target. The criticality of the targets made of pure ${ }^{241} \mathrm{Am}$ and ${ }^{243} \mathrm{Am}$ is investigated by applying the Monte Carlo code for ADS [12]. The neutronic data of several infinite target mediums irradiated with a proton source of $1000 \mathrm{MeV}$ is studied by Yapic1 et al. [13] to attain a real ADS design. Yapic1 et al. [14] and Bakir et al. [15] bring out that a high neutronic performance in nuclear waste transmutation, fissile breeding, and energy generation can be obtained for various considered configurations and fuel compositions of an ADS. Martínez et al. [16] claim that high-energetic neutrons are necessitated for transmutation of transuranium (TRU) and long-lived fission products in ADS. There are several other studies of various types of ADS for energy production and transmutation of radioactive wastes (Adam et al. [17]; Artisyuk et al. [18]; Brolly and Vértes, [19]; Haeck et al. [20]; Mukaiyama et al. [21]; Park et al. [22]; Seltborg and Wallenius [23]; Tsujimoto et al. [24]; Wade et al. [25]; Wallenius and Eriksson [26]; Westlén and Wallenius [27]).

The main cause of temperature and radiation damage gradients in an ADS is the nonuniform fission power density. Therefore, power flattening can help cooling of fuel core and reduce material stresses. To obtain a uniform fission power density profile, peak-to-average fission power density ratio $(\Gamma)$ is expected to be reduced to 1.00. Power flattening of the helium-cooled DT driven blanket in the Prometheus- $\mathrm{H}$ (heavy ion) breeder reactor fuelled with various mixed fuels (UC-ThC, $\mathrm{UO}_{2}-\mathrm{ThO}_{2}, \mathrm{UC}-\mathrm{C}, \mathrm{UO}_{2}-\mathrm{C}$, and ${ }^{244} \mathrm{CmO}_{2}-\mathrm{UO}_{2}$ ) and nuclear waste actinide are studied by Yapıcı and Übeyli [28]. According to their results, high amounts of energy, fissile fuel, and self-sufficient tritium production for $(\mathrm{D}, \mathrm{T})$ fusion reaction are obtained. Fissile fuel breeding and a flat fission power density are examined by Yapic1 [29] in a blanketdriven ICF (inertial confinement fusion) neutron and based on $\mathrm{SiC}_{\mathrm{f}} / \mathrm{SiC}$ composite material. In order to accomplish a flat fission power density, the blanket is fuelled with $\mathrm{ThO}_{2}$ and $\mathrm{UO}_{2}$ mixed by several different mixing methods and cooled with natural lithium, $(\mathrm{LiF})_{2} \mathrm{BeF}_{2}, \mathrm{Li}_{17} \mathrm{~Pb}_{83}$, and ${ }^{4} \mathrm{He}$ for the nuclear heat transfer. Peak-to-average fission power density ratio of the blanket is decreased to almost 1.1. Bakır et al. [30] have investigated the medical radioisotope production performance of a power-flattened ADS fuelled with $\mathrm{UO}_{2}$ and $\mathrm{PuO}_{2}$. Their results show that a good quasi-uniform power density is achieved and good neutronic performance in terms of energy production, radioisotope production, and the transmutation of spent fuel is also achieved.

In this study, power flattening and time-dependent neutronic analysis of a conceptual helium gas cooled ADS loaded with TRISO fuel particles are presented. The paper is organized as follows. In Section 2, the computational model of a conceptual gas cooled ADS is explained. Calculation

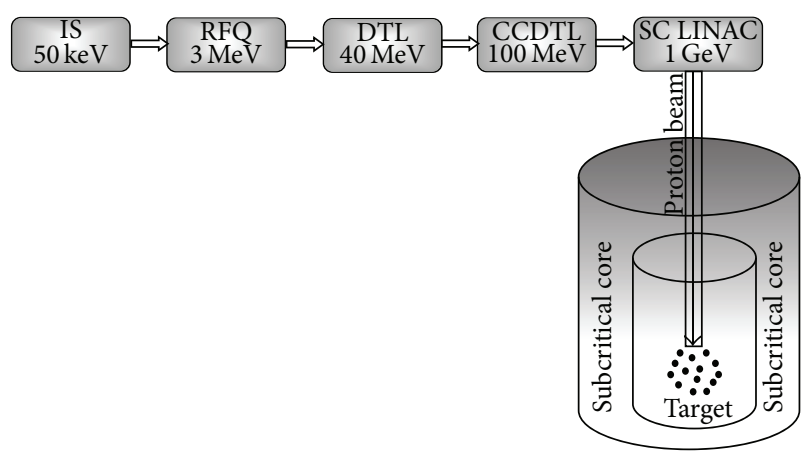

FIGURE 1: Layout of the $1 \mathrm{GeV}$ LINAC for ADS (IS: ion source; RFQ: radio frequency quadrupol; DTL: drift tube LINAC; CCDTL: cavity coupled DTL; SC LINAC: superconducting linear accelerator).

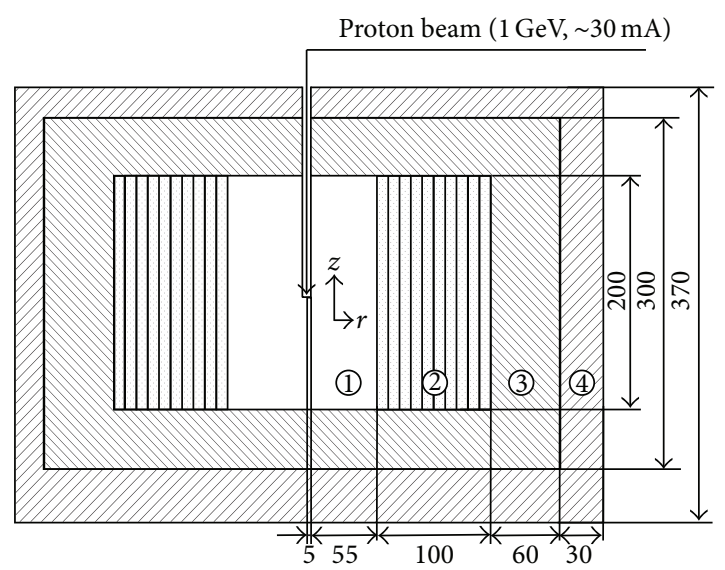

FIGURE 2: Cross-sectional view of the investigated ADS (1) SNT: spallation neutron target; (2) SCZ: Subcritical Core Zone; (3) RZ: reflector zone; (4) SZ: shielding zone; dimensions are in $\mathrm{cm}$ ).

procedure is outlined in Section 3. Numerical results and conclusions are presented in Sections 4 and 5, respectively.

\section{Conceptual Gas Cooled Accelerator Driven System}

Figure 1 demonstrates the layout of $1000 \mathrm{MeV}$ linear accelerator (LINAC) for an ADS. As is apparent from this figure, a proton of $50 \mathrm{keV}$ is accelerated to $1000 \mathrm{MeV}$ in four steps: ion source (IS) of $50 \mathrm{keV}$ is accelerated firstly to $3 \mathrm{MeV}$ by radio frequency quadrupole (RFQ), secondly to $40 \mathrm{MeV}$ by drift tube LINAC (DTL), thirdly to $100 \mathrm{MeV}$ by cavity coupled DTL (CCDTL), and finally to $1000 \mathrm{MeV}$ by superconducting linear accelerator (SC LINAC).

Figures 2 and 3 show the cross-sectional view of the investigated conceptual cylindrical ADS and TRISO coated fuel particles in the fuel pebble sphere, respectively. There are four parts in the considered ADS as follows: spallation neutron target (SNT), subcritical core (SC), reflector zone (RZ), and shielding zone (SZ). In order to obtain flattened power profiles in SC, this core is radially divided into 10 equidistant subzones (see Figure 2). The isotopic percentages 


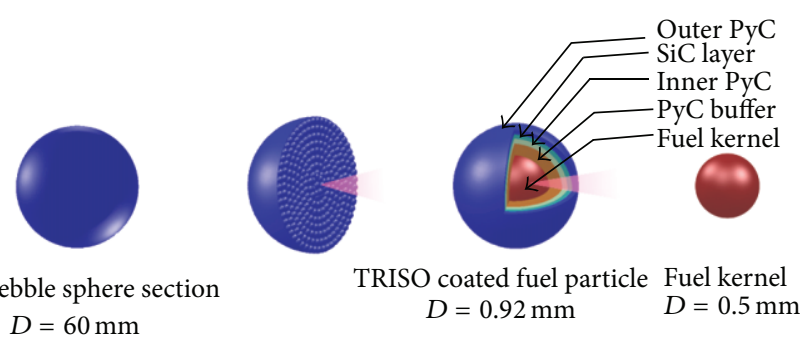

FIGURE 3: Fuel pebble sphere and TRISO coated fuel particle (PyC: pyrocarbon; SiC: silicon carbide).

TABLE 1: Isotopic percentages and densities of the materials used in the investigated ADS.

\begin{tabular}{lccc}
\hline Material & Density $\left[\mathrm{g} / \mathrm{cm}^{3}\right]$ & Nuclide & Percentage \\
\hline $\mathrm{LBE}$ & 11.344 & $\mathrm{~Pb}$ & 44.5 \\
& 9.8 & $\mathrm{Bi}$ & 55.5 \\
\hline $\mathrm{He}$ & 0.1786 & $\mathrm{He}$ & 100 \\
\hline $\mathrm{ThO}_{2}$ & 9.88 & ${ }^{232} \mathrm{Th}$ & 100 \\
\hline $\mathrm{UO}_{2}$ & 10.54 & ${ }^{235} \mathrm{U}$ & $7.5,15,22.5$ \\
& & ${ }^{238} \mathrm{U}$ & $92.5,85,77.5$ \\
\hline & & ${ }^{238} \mathrm{Pu}$ & 3.53535 \\
${ }^{*} \mathrm{PuO}_{2}$ & 11.50 & ${ }^{239} \mathrm{Pu}$ & 45.0154 \\
& & ${ }^{240} \mathrm{Pu}$ & 26.3505 \\
& & ${ }^{241} \mathrm{Pu}$ & 15.9640 \\
& & ${ }^{242} \mathrm{Pu}$ & 9.13483 \\
\hline${ }^{*} \mathrm{CmO}_{2}$ & 10.55 & ${ }^{242} \mathrm{Cm}$ & 3.91520 \\
& & ${ }^{243} \mathrm{Cm}$ & 0.04721 \\
& & ${ }^{244} \mathrm{Cm}$ & 85.5422 \\
\hline $\mathrm{Graphite}^{245} \mathrm{Cm}$ & 9.54125 \\
$\mathrm{~B}_{4} \mathrm{C}$ & 2.10 & ${ }^{246} \mathrm{Cm}$ & 0.95413 \\
\hline
\end{tabular}

${ }^{*}$ Discharged PWR-MOX fuel with plutonium recycle, 1000 MWe reactor, $80 \%$ capacity factor, $33 \mathrm{MWd} / \mathrm{kg}, 2.5 \%$ thermal efficiency, and 150 days after discharge [32, p. 370, Table 8.5].

TABLE 2: Characteristics of a TRISO particle [31].

\begin{tabular}{lccc}
\hline Layer & Size $[\mu \mathrm{m}]$ & Material & Density $\left[\mathrm{g} / \mathrm{cm}^{3}\right]$ \\
\hline Fuel kernel & 250 (radius) & $\mathrm{UO}_{2}$ & 10.55 \\
PyC buffer & 95 (thickness) & $\mathrm{C} / \mathrm{C}$ & 1.05 \\
Inner PyC & 40 (thickness) & $\mathrm{C} / \mathrm{C}$ & 1.90 \\
SiC layer & 35 (thickness) & $\mathrm{SiC}$ & 3.18 \\
Outer PyC & 40 (thickness) & $\mathrm{C} / \mathrm{C}$ & 1.90 \\
\hline
\end{tabular}

and densities of the materials used in this ADS are given in Table 1. Geometric characteristics of a TRISO particle (Kim et al. [31]) are given in Table 2.

Spallation Neutron Target. The target is liquid lead- ( $\mathrm{Pb}-)$ bismuth (Bi) eutectic, (LBE: $44.5 \% \mathrm{~Pb}-55.5 \%$ Bi eutectic). Due to its good neutron release characteristic and thermal and chemical properties, the LBE is the most preferable target material for ADS designs among many target materials in the literature [33]. The radius of the target is optimized as $55 \mathrm{~cm}$ in terms of spallation neutrons. A continuous uniform proton beam of $1000 \mathrm{MeV}$ and a source radius of $4 \mathrm{~cm}$ bombards the target to release a few tens of high-energy spallation neutrons. In this work, the target radius is gradually increased to optimize neutron leakage. It is determined as $55 \mathrm{~cm}$ and neutron leakage is calculated as about 30 neutrons per proton. The release neutrons penetrate through SC to activate fission and breeding reactions.

Subcritical Core. Tristructural-isotropic (TRISO) fuel is originated from a kernel made of fuel such as uranium carbide/uranium oxide and surrounded by carbon and ceramic layer. The TRISO fuel is an attractive fuel for high temperature nuclear reactors due to the fact that it has a quite high neutronic performance and good burn-up ability in high temperatures. As is apparent from Figure 3 and Table 2, a microspherical tristructural-isotropic (TRISO) fuel particle is designed as five layers from the inside out as follows: (1) fuel kernel, (2) Porous Carbon Buffer, (3) Inner Pyrolytic Carbon (IPyC), (4) silicon carbide (SiC), and (5) Outer Pyrolytic (OPyC) (see Figure 3) (Kim et al. [31]). Dimensions of these layers are given in Table 2. These TRISO composite particles are embedded inside a spherical carbon matrix fuel pebble with a determined packing fraction which can be up to $32 \%$ (Conway and Sloane [34]). Spherical fuel pebble is made of carbon matrix having a $60 \mathrm{~mm}$ diameter (see Figure 3). These carbon matrix fuel pebbles are located in a cylindrical SC with a determined packing fraction which can be up to $74 \%$ (Conway and Sloane [34]). In this study, to produce fissile fuel and energy and to transmute PWR-MOX spent fuel, tens of thousands of six different TRISO fuel particles $\left(\mathrm{ThO}_{2}\right.$, average $9 \%$ enrichment $\mathrm{UO}_{2}, 15 \%$ enriched $\mathrm{UO}_{2}, 22.5 \%$ enriched $\mathrm{UO}_{2}, \mathrm{PuO}_{2}$, and $\mathrm{CmO}_{2}$ ) are embedded in the carbon matrix fuel pebbles with a packing factor of $29 \%$ as five different cases as follows and the embedding percentages of different TRISO fuel particles in the carbon matrix fuel pebbles in each subzone are given in Table 3.

Case 1. (a) Only $\mathrm{UO}_{2}$ TRISO particles with different enrichment percentages $(3.20 \%-11.25 \%)$ are embedded in the carbon matrix fuel pebbles and tens of thousands of these fuel pebbles are located in the ten equidistant layers according to their enrichment percentages.

(b) $\mathrm{ThO}_{2}$ and $15 \%$ enriched $\mathrm{UO}_{2}$ TRISO particles are separately embedded in the carbon matrix fuel pebbles with 
TABLE 3: Enrichment percentages of $\mathrm{UO}_{2}$ TRISO particles (Case $1(\mathrm{a})$ ) and embedding percentages of $15 \%$ enriched $\mathrm{UO}_{2}, 22.5 \%$ enriched $\mathrm{UO}_{2}$, $\mathrm{PuO}_{2}$, and $\mathrm{CmO}_{2}$ TRISO particles in Cases 1(b), 1(c), 2, and 3 in the fuel pebbles in the fuel subzones at the beginning of cycle $\left[P_{\text {th }}=1000 \mathrm{MW}\right]$.

\begin{tabular}{|c|c|c|c|c|c|c|c|c|c|c|c|}
\hline \multirow{2}{*}{ Case } & \multicolumn{11}{|c|}{ Number of the subzones } \\
\hline & 1 & 2 & 3 & 4 & 5 & 6 & 7 & 8 & 9 & 10 & $1-10^{*}$ \\
\hline 1(a) & 8.52 & 9.32 & 9.82 & 10.25 & 10.75 & 11.25 & 11.25 & 9.92 & 6.47 & 3.20 & 7.5 \\
\hline 1(b) & 70.00 & 78.50 & 83.00 & 86.50 & 89.00 & 93.00 & 94.50 & 93.00 & 63.50 & 28.00 & 71.00 \\
\hline 1(c) & 47.00 & 56.00 & 60.50 & 63.50 & 66.50 & 68.50 & 69.50 & 66.00 & 43.00 & 18.25 & 46.00 \\
\hline 2 & 20.30 & 26.00 & 27.90 & 28.85 & 29.76 & 31.40 & 33.65 & 35.55 & 26.80 & 6.76 & 26.50 \\
\hline 3 & 7.90 & 7.80 & 7.80 & 7.90 & 8.10 & 8.31 & 8.31 & 7.42 & 6.01 & 4.04 & 6.45 \\
\hline
\end{tabular}

${ }^{*}$ Constant enrichment percentage or constant embedding percentages in all subzones.

different embedding percentages and tens of thousands of these fuel pebbles are located in the ten equidistant layers according to their embedding percentages.

(c) $\mathrm{ThO}_{2}$ and $22.5 \%$ enriched $\mathrm{UO}_{2}$ TRISO particles are separately embedded in the carbon matrix fuel pebbles with different embedding percentages and tens of thousands of these fuel pebbles are located in the ten equidistant layers according to their embedding percentages.

Case 2. $\mathrm{ThO}_{2}$ and $\mathrm{PuO}_{2}$ TRISO particles are separately embedded in the carbon matrix fuel pebbles with different embedding percentages and tens of thousands of these fuel pebbles are located in the ten equidistant layers according to their embedding percentages.

Case 3. $\mathrm{ThO}_{2}$ and $\mathrm{CmO}_{2}$ TRISO particles are separately embedded in the carbon matrix fuel pebbles with different embedding percentages and tens of thousands of these fuel pebbles are located in the ten equidistant layers according to their embedding percentages.

Packing factor of the carbon matrix fuel pebbles in SC is $60 \%$. This core is cooled with helium gas whose percentage is $40 \% . \mathrm{PuO}_{2}$ and $\mathrm{CmO}_{2}$ fuels mentioned above are extracted from PWR-MOX spent fuels (Manson et al. [32]), fuel with plutonium recycle, $1000 \mathrm{MWe}$ reactor, $80 \%$ capacity factor, $33 \mathrm{MWd} / \mathrm{kg}$, 32.5\% thermal efficiency, and 150 days after discharge.

Neutron Safety. The last two zones (RZ and SZ) serve for neutron safety. Reflector part is the zone made of graphite reflecting neutrons leaking from the SC zone to increase fission and breeding reactions. The graphite is selected because its scatter cross section is much greater than its absorption cross section. Additionally, it is a good neutron moderator and is high temperature resistant. Because of these properties, the graphite is widely preferable in nuclear applications. Shielding part is the last zone made of boron carbide $\left(\mathrm{B}_{4} \mathrm{C}\right)$ absorbing the neutrons leaking from RZ. Due to the fact that boron has a quite high absorption cross section and $\mathrm{B}_{4} \mathrm{C}$ has good thermomechanical properties, $\mathrm{B}_{4} \mathrm{C}$ is usually used in nuclear reactors.

\section{Calculation Procedure}

The numerical calculations have been computed by using the high-energy Monte Carlo code MCNPX 2.7
(Pelowitz et al. [35]) with the LA150 library (Chadwick et al. [36]). "The library consists of evaluated reaction crosssections and emission spectra up to $150 \mathrm{MeV}$ for incident neutrons and protons, for over 40 target isotopes important in SNTs, structural materials, and shielding" (Yapıcı et al. [14]). Model for the intranuclear cascade of spallation reactions is selected as Bertini INC model (Bertini, [37]). The literature and our previous studies (Yapic1 et al. $[13,14]$ ) bring out that the energy gain $(G)$ is at the maximum level at proton energy $\left(E_{p}\right)$ of $1000 \mathrm{MeV}$. Therefore, source proton energy is assumed as $1000 \mathrm{MeV}$ (see Figure 2). The BURN card of the MCNPX 2.7 code (Pelowitz et al. [35]) is used for time-dependent calculations and these calculations are performed for the power-flattened cases.

\section{Numerical Results}

4.1. Effective Neutron Multiplication Coefficient. The effective neutron multiplication coefficient $\left(k_{\text {eff }}\right)$ is the ratio of one generation of neutrons to the next generation. This coefficient is less than 1 in the subcritical systems. The compositions of the fuels in this study are determined in all cases so that $k_{\text {eff }}$ is 0.98 at the beginning of the burn cycle. Thermal fission power $\left(P_{\mathrm{th}}\right)$ is considered as $100,300,500,700$, and $1000 \mathrm{MW}$ for the burn-up calculations. Figures 4-6 demonstrate the variations of $k_{\text {eff }}$ with the operation time (a) and the burn cycle times calculated according to the decrease of $k_{\text {eff }}$ from 0.95 to 90 (b) for all fuel cases.

As is apparent from (a) of Figures 4-6, the profiles of $k_{\text {eff }}$ gradually decline with the operation time in all $P_{\mathrm{th}}$ 's and fuel cases. These profiles indicate that fissile isotopes are consumed by burning with the operation time. For all values of $k_{\text {eff }}(0.90-0.95)$, the operation times shorten exponentially with the increase of $P_{\text {th }}$ (see (b) of Figures 4-6). For $P_{\text {th }}=$ $1000 \mathrm{MW}$, the times that $k_{\text {eff }}$ decreases from 0.98 to 0.95 are $0.75,1.25$, and 1.25 days in Cases $1(\mathrm{a}), 1(\mathrm{~b})$, and $1(\mathrm{c})$ (including natural, $15 \%$ and $22.5 \%$ enriched $\mathrm{UO}_{2}$ TRISO particles), respectively. These times are 30 days and half a day in Cases 2 and $3\left(\mathrm{PuO}_{2}\right.$ and $\mathrm{CmO}_{2}$ spent fuel TRISO particles). To prevent energy gain $(G)$ from decreasing significantly, the fuel pebbles are refreshed when the value of $k_{\text {eff }}$ decreases from 0.98 to 0.95 .

4.2. Fission Power Density. Large numbers of energetic spallation and fission neutrons are released in SNT and SC of an ADS, and in turn, more fission reactions occur in SC. 

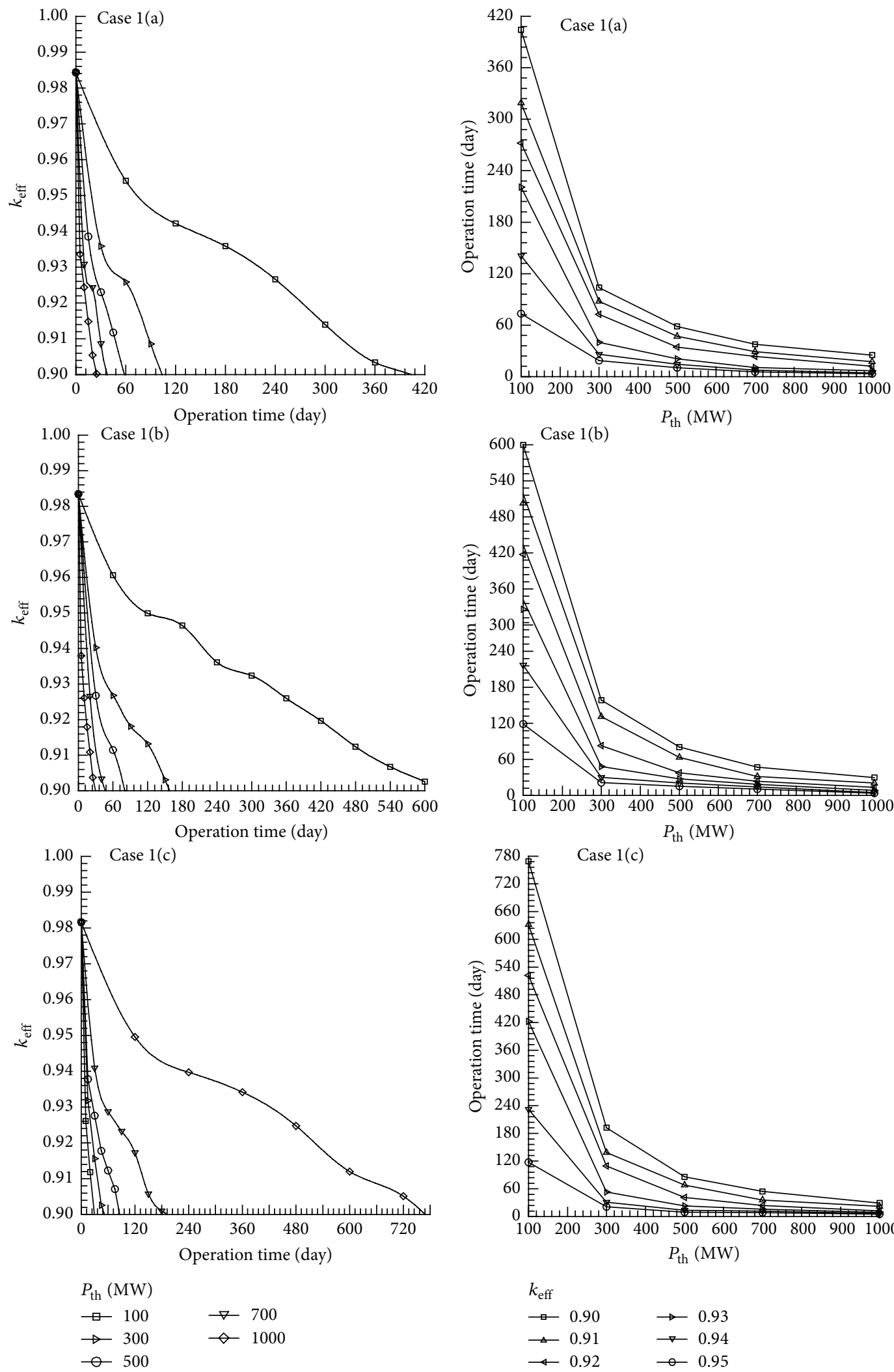

$P_{\mathrm{th}}(\mathrm{MW})$

$\longrightarrow$
$\longrightarrow \quad 300$

$\rightarrow 700$

- 500

$\diamond 1000$

(b)

FIGURE 4: (a) Variations of the effective neutron multiplication in the various cases of thermal power depending on the operation time. (b) The operation time at which effective neutron multiplication reached various values $(0.90-0.95)$ versus the thermal power. 


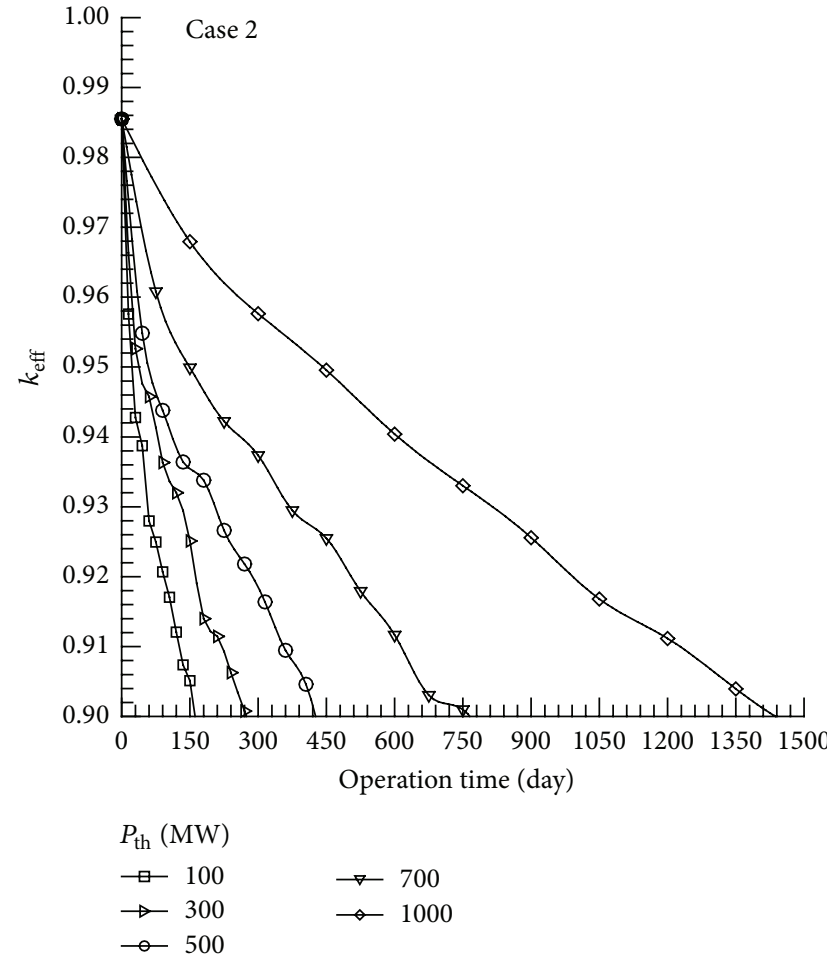

(a)

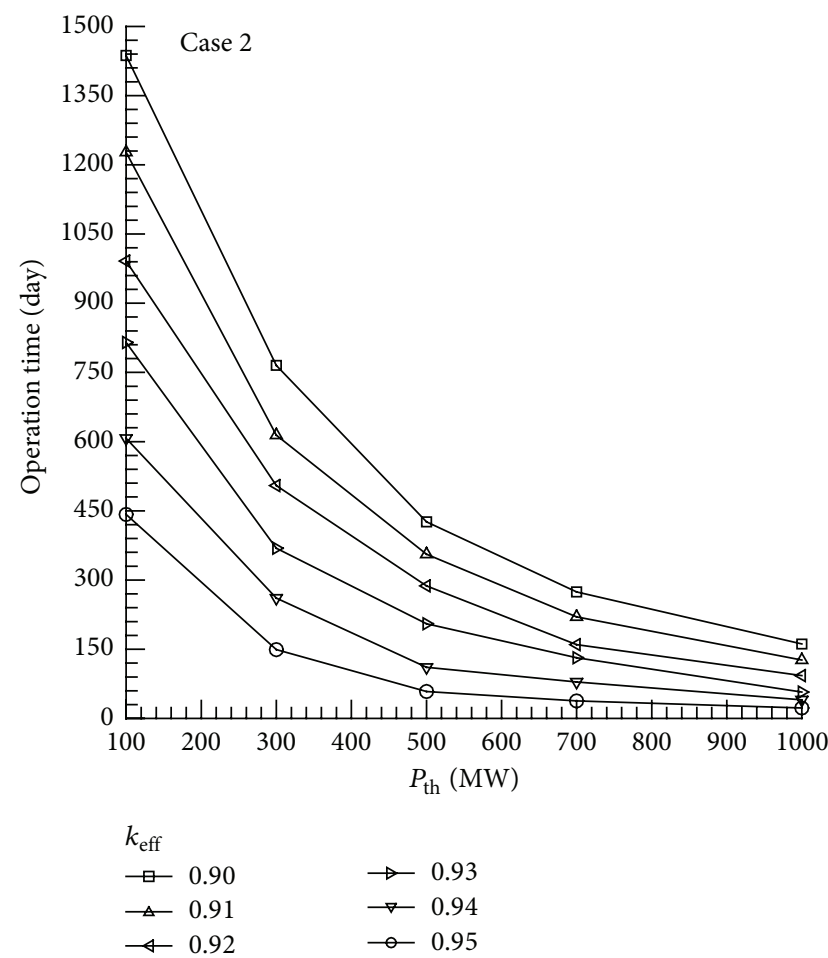

(b)

Figure 5: (a) Variations of the effective neutron multiplication in the various cases of thermal power depending on the operation time. (b) The operation time at which effective neutron multiplication reached various values $(0.90-0.95)$ versus the thermal power.

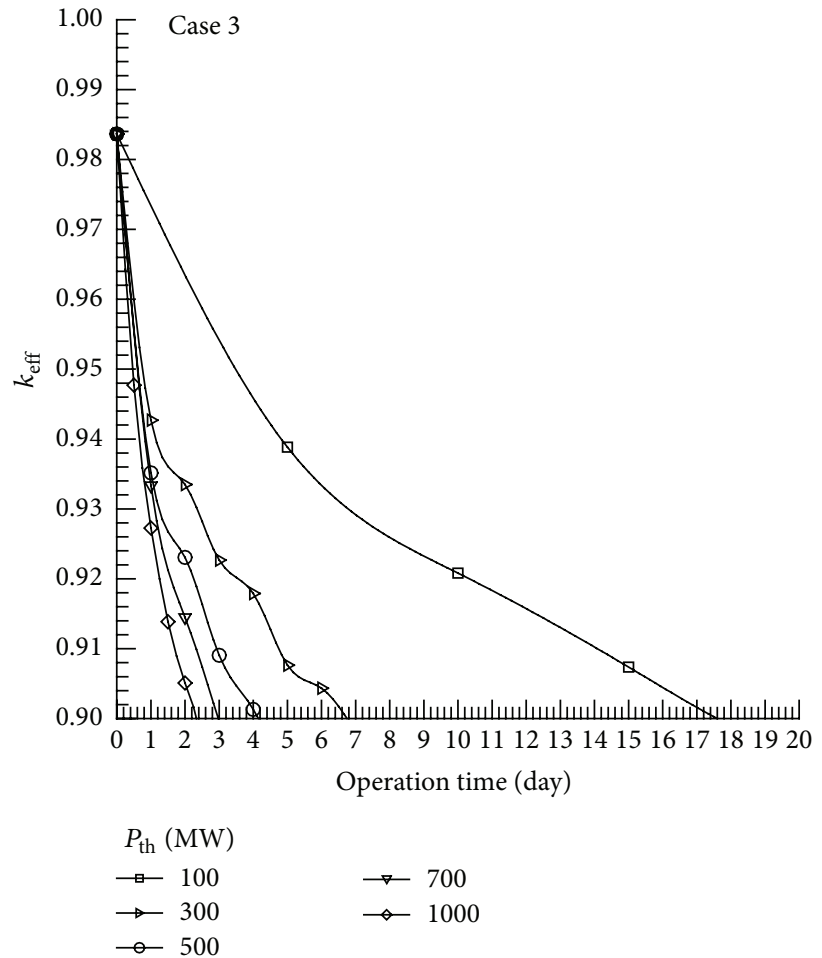

(a)

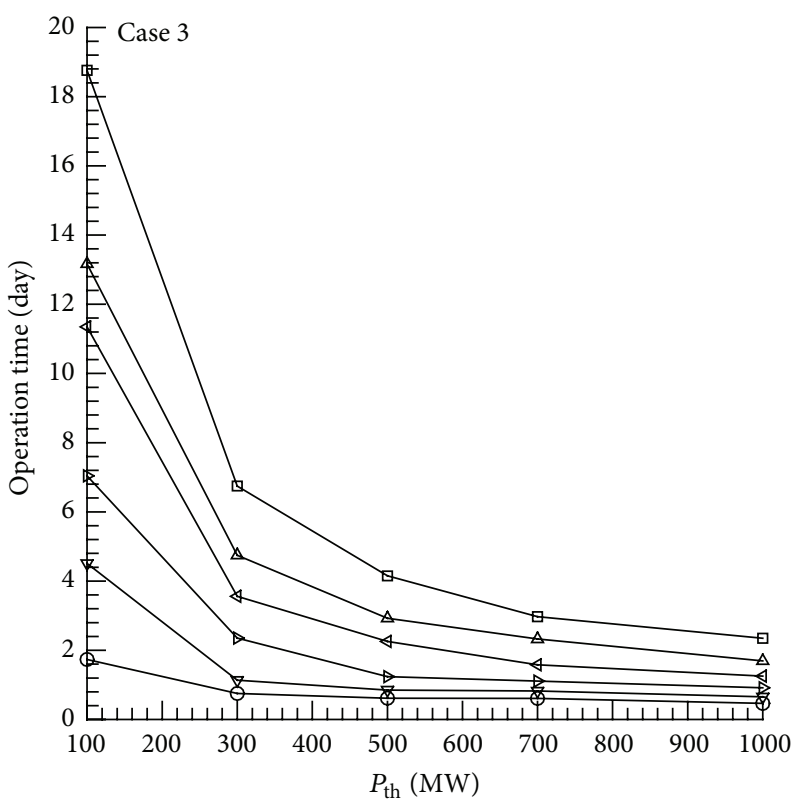

$k_{\text {eff }}$

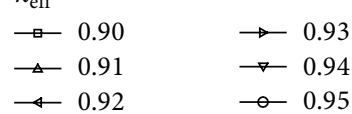

(b)

FIgURE 6: (a) Variations of the effective neutron multiplication in the various cases of thermal power depending on the operation time. (b) The operation time at which effective neutron multiplication reached various values $(0.90-0.95)$ versus the thermal power. 

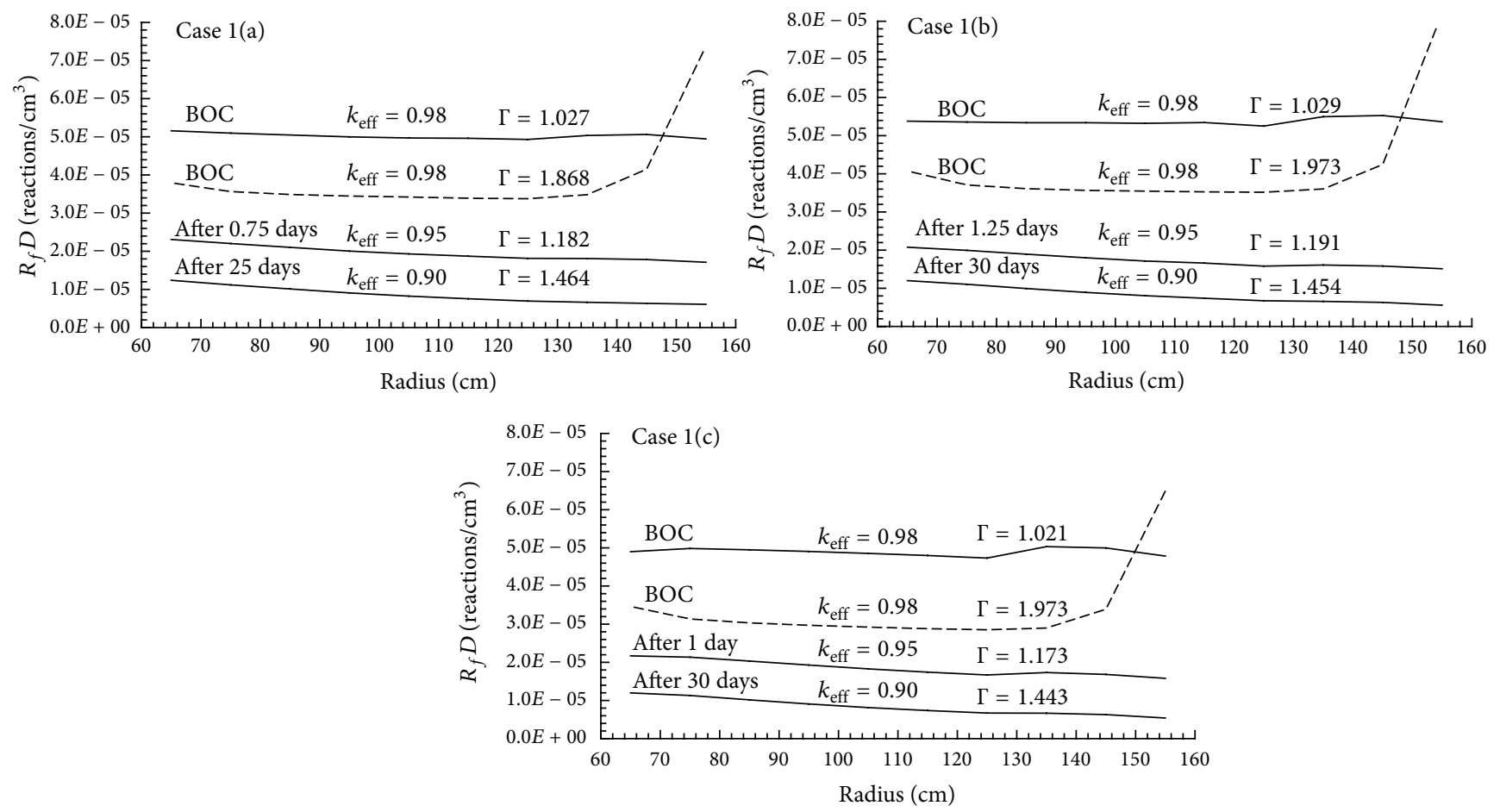

Figure 7: Variations of fission densities in the fuel core at the beginning and at the end of the cycle versus the core radius (solid lines indicate the flattened power case).

From inner side to outer side of SC in radial direction, profile of the fission power density declines exponentially because of the decrease of neutron fluxes in this direction. This nonuniformity of fission power density causes radiation damage and large temperature gradients that result in cooling and material issues. This situation is usually observed in ADSs and similar nuclear power systems. On the contrary, a uniform fission power density would help preventing of these cooling and material damage problems. A measure of uniformity of fission power density profile is determined with the peak-to-average fission power density ratio. This ratio must be 1.00 for an exact uniform fission power density profile.

In this work, in order to achieve a uniform power profile in SC, this core is radially divided into 10 equidistant subzones (see Figure 2), and the embedding percentages of different TRISO fuel particles in the carbon matrix fuel pebbles in each subzone of SC are adjusted in radial direction. The embedding percentages are optimized after many computational trials of percentages (see Table 3). The fission power density profiles obtained in the cases without percentage adjustments (constant percentages in all subzones) and in the cases with percentage adjustments (varying percentages in all subzones) are plotted in Figures 7-9 for all fuel cases. Dashed lines in these figures indicate the cases without percentage adjustments. In general, uniformity of power profiles of the cases without percentage adjustments breaks down (the profiles sharply increase) in the last subzones because of neutrons reflecting from RZ. On the other hand, in the optimized adjustment cases, quasi-uniform power profiles

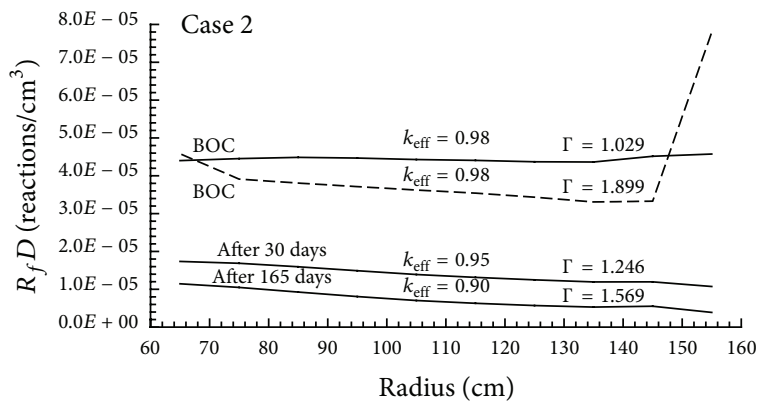

FIgURE 8: Variations of fission densities in the fuel core at the beginning and at the end of the cycle versus the core radius (solid lines indicate the flattened power case).

are achieved for all fuel cases. At the beginning of cycle (BOC), the values of $\Gamma$ are reduced to between 1.021 and 1.029 in Cases $1(\mathrm{a})-1(\mathrm{c})$, and as to Cases 2 and 3, these values are 1.029 and 1.024, respectively. It is important to note that these values are lower with respect to the values obtained from Yapıc1 and Übeyli $[28](\Gamma=1.051-1.069)$ and Yapıc1 [29] $(\Gamma=1.131-1.403)$. The uniformity of power profile does not deteriorate significantly until $k_{\text {eff }}$ decreases to 0.95 . These values and power profiles bring out that the power of the investigated ADS is flattened for all fuel cases.

4.3. Fuel Burn-up. Burn-up (BU) is defined as the total energy generated per initial unit mass of initially loaded fuel, and its unit is GWd/MTU (GWd: gigawatt days; MTU: per 
TABLE 4: Increase of burn-up with the thermal power and time.

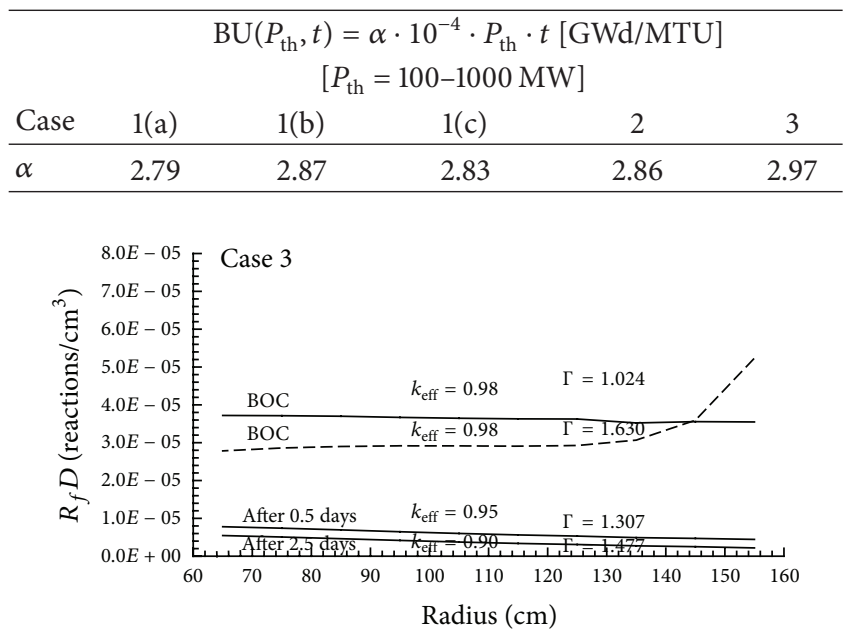

FIgURE 9: Variations of fission densities in the fuel core at the beginning and at the end of the cycle versus the core radius (solid lines indicate the flattened power case).

metric ton of uranium). So it is directly related to the fission reactions and calculated as follows:

$$
\mathrm{BU}(t+\Delta t)=\mathrm{BU}(t)+\frac{\text { Fission Energy }}{\mathrm{MTU}} \Delta t,
$$

where $t$ is operation time and $\Delta t$ is time interval.

The calculations emphasize that the values of BU increase quasi-linearly in all $P_{\mathrm{th}}$ 's with operation time. In order to find an empirical relation for BU, curve-fitting method is used. Curve-fitting method gives the relation between independent variables and dependent variable by applying the best fit to data. The coefficients of the BU profiles obtained by this method are given in Table 4 for all fuel cases. The operation time limits in this $\mathrm{BU}\left(P_{\mathrm{th}}, t\right)$ expression are between the BOC and the end of cycle (EOC) which varies depending on the fuel cases (see footnote of Table 5). The longest EOC time is in Case 2 and it is 30 days for $k_{\text {eff }}=0.95$. In this operation time, the $\mathrm{BU}$ value is $8.58 \mathrm{GWd} / \mathrm{MTU}$ for $P_{\mathrm{th}}=1000 \mathrm{MW}$.

4.4. Gain. The energy gain proportional to fission reactions $\left(R_{f}\right)$ occurring in SC is one of the most major parameters of an ADS. It can be defined as the ratio of the total fission energy production in the core to $E_{p}$ and calculated as follows:

$$
G=\frac{R_{f} E_{f}}{E_{p}}
$$

or

$$
G=\frac{P_{\text {th }}}{\mathrm{PE}},
$$

where $E_{f}$ is the energy per fission $(200 \mathrm{MeV})$ and $\mathrm{PE}$ is the proton beam power.

The gain values of the investigated ADS, calculated for $P_{\text {th }}=1000 \mathrm{MW}$ at the BOC and the EOC, are given in Table 5 .
While these values vary in the range of $99.98-148.64$ at the BOC depending on the fuel case, this range is $15.68-52.71$ at the EOC $\left(k_{\text {eff }}=0.95\right)$. Case $1(\mathrm{~b})$ (including $15 \%$ enriched $\mathrm{UO}_{2}$ TRISO particles) among Cases $1(\mathrm{a})-1(\mathrm{c})$ is the best fuel case in terms of the energy gain. As for the spent fuel cases, Case 2 (including $\mathrm{PuO}_{2}$ TRISO particles) is the best. In order to maintain $P_{\text {th }}=1000 \mathrm{MW}$, the value of proton flux $(\mathrm{PF})$ is varied in the range of $0.420 \cdot 10^{17}-0.624 \cdot 10^{17}$ protons/s at the $\mathrm{BOC}$ depending on the fuel case; and during the operation, $\mathrm{PF}$ is increased to the range of 1.184 to $3.981 \times 10^{17}$ protons/s. $10^{17}$ protons of $1000 \mathrm{MeV}$ of energy per second correspond to a PE of 16.02 MW.

4.5. Thorium Utilization. As known, thorium utilization means production of fissile ${ }^{233} \mathrm{U}$. This production reaction is as follows:

$$
{ }^{232} \mathrm{Th}(\mathrm{n}, \gamma){ }^{233} \mathrm{Th} \stackrel{\beta}{\longrightarrow}{ }^{233} \mathrm{~Pa} \stackrel{\beta}{\longrightarrow}{ }^{233} \mathrm{U}
$$

Masses of isotopes which are loaded to SC at the BOC and produced in this core at the EOC are given in Tables 6-8 for all fuel cases. Although the highest thorium load ( $3114 \mathrm{kgHM}$ ) is in Case 3 (including $\mathrm{CmO}_{2}$ TRISO particles), the best thorium utilization is realized in Case 2. As for the cases with uranium, Case 1(c) (including 22.5\% enriched $\mathrm{UO}_{2}$ TRISO particles) is the best case among Cases $1(\mathrm{a})-1$ (c) due to the fact that it has more enrichment uranium. Fissile fuel ${ }^{233} \mathrm{U}$ of $155.1 \mathrm{~g}$ per day $(4.653 \mathrm{~kg} / 30$ days) and $6.1 \mathrm{~g}$ per day $\left(7.619 \cdot 10^{-3} \mathrm{~kg} / 1.25\right.$ days $)$ is produced by utilizing thorium for $k_{\text {eff }}=0.95$ in Cases 2 and 1(c), respectively.

In addition to these, fissile fuel ${ }^{239} \mathrm{Pu}$ of $103.6 \mathrm{~g}$ per day $\left(1.295 \cdot 10^{-1} \mathrm{~kg} / 1.25\right.$ days $)$ and $77.6 \mathrm{~g}$ per day $(9.697$. $10^{-2} \mathrm{~kg} / 1.25$ days) is produced by utilizing uranium for $k_{\text {eff }}=$ 0.95 in Cases $1(\mathrm{~b})$ and $1(\mathrm{c})$, respectively. Reaction of ${ }^{239} \mathrm{Pu}$ produced from ${ }^{238} \mathrm{U}$ is as follows:

$$
{ }^{238} \mathrm{U}(\mathrm{n}, \gamma){ }^{239} \mathrm{U} \stackrel{\beta}{\longrightarrow}{ }^{239} \mathrm{~Np} \stackrel{\beta}{\longrightarrow}{ }^{239} \mathrm{Pu}
$$

\section{Conclusion}

One way of transmutation of nuclear wastes is using ADSs by driving high-energetic proton source. In this study, a conceptual LBE target-ADS has been investigated to transmute spent fuel with thorium and to flatten the fission power density of the fuel core, as well as energy production. Many time-dependent computational trials have been performed to obtain optimum neutronic data by using MCNPX 2.7 computer code. The major results are, in brief, as follows:

(i) The optimized radius $(55 \mathrm{~cm})$ of $\mathrm{LBE}$ target is the best size in terms of spallation neutrons (about 30 neutrons).

(ii) The longest and shortest times when $k_{\text {eff }}$ decreases to 0.95 are in Case 2 (including $\mathrm{ThO}_{2}$ and $\mathrm{PuO}_{2}$ TRISO particles) and Case 3 (including the $\mathrm{ThO}_{2}$ and $\mathrm{CmO}_{2}$ TRISO particles), which are 0.5 days and 30 days, respectively. After these times, the fuel pebbles should be refreshed. 
TABle 5: Neutronic data at the beginning and at the end of the cycle.

\begin{tabular}{|c|c|c|c|c|c|c|}
\hline \multirow{2}{*}{\multicolumn{2}{|c|}{$P_{\text {th }}=1000 \mathrm{MW}$}} & \multicolumn{5}{|c|}{ Case } \\
\hline & & $1(\mathrm{a})$ & (b) & $1(\mathrm{c})$ & 2 & 3 \\
\hline \multirow{3}{*}{ Fission } & BOC $^{*}$ & 692.17 & 743.24 & 675.64 & 615.68 & 499.92 \\
\hline & $\mathrm{EOC}^{* *}$ & $263.56^{1}$ & $234.39^{3}$ & $248.73^{5}$ & $179.48^{7}$ & $78.38^{9}$ \\
\hline & $\mathrm{EOC}^{* * *}$ & $109.81^{2}$ & $106.88^{4}$ & $107.48^{6}$ & $94.01^{8}$ & $47.34^{10}$ \\
\hline \multirow{3}{*}{$G$} & BOC & 138.43 & 148.64 & 135.13 & 123.14 & 99.98 \\
\hline & EOC & 52.71 & 46.88 & 49.75 & 35.90 & 15.68 \\
\hline & EOC & 21.96 & 21.38 & 21.50 & 18.80 & 9.47 \\
\hline \multirow{3}{*}{$\mathrm{PE}[\mathrm{MW}]$} & BOC & 7.22 & 6.73 & 7.40 & 8.12 & 10.00 \\
\hline & EOC & 18.97 & 21.33 & 20.10 & 27.85 & 63.77 \\
\hline & EOC & 45.54 & 46.77 & 46.51 & 53.19 & 105.60 \\
\hline \multirow{3}{*}{$\mathrm{PF} \times 10^{17}[\mathrm{p} / \mathrm{s}]$} & $\mathrm{BOC}$ & 0.451 & 0.420 & 0.462 & 0.507 & 0.624 \\
\hline & EOC & 1.184 & 1.331 & 1.255 & 1.738 & 3.981 \\
\hline & EOC & 2.843 & 2.919 & 2.903 & 3.320 & 6.592 \\
\hline
\end{tabular}

${ }^{*} k_{\text {eff }}=0.98,{ }^{* *} k_{\text {eff }}=0.95$, and ${ }^{* * *} k_{\text {eff }}=0.90$

${ }^{1}$ After 0.75 days. ${ }^{2}$ After 25 days.

${ }^{3}$ After 1.25 days. ${ }^{4}$ After 30 days.

${ }^{5}$ After 1.25 days. ${ }^{6}$ After 30 days.

${ }^{7}$ After 30 days. ${ }^{8}$ After 165 days.

${ }^{9}$ After 0.5 days. ${ }^{10}$ After 2.5 days.

TABLE 6: Masses of actinide isotopes [kgHM] at the beginning and at the end of the cycle (Cases 1(a)-1(c)).

\begin{tabular}{|c|c|c|c|c|c|c|c|c|c|}
\hline Case & & 1(a) & & & 1(b) & & & $1(\mathrm{c})$ & \\
\hline Isotopes & $\mathrm{BOC}$ & $\mathrm{EOC}^{1}$ & EOC $^{2}$ & $\mathrm{BOC}$ & $\mathrm{EOC}^{3}$ & EOC $^{4}$ & $\mathrm{BOC}$ & EOC $^{5}$ & EOC $^{6}$ \\
\hline${ }^{231} \mathrm{Th}$ & - & - & - & - & $7.448 E-5$ & $1.597 E-4$ & - & $1.680 E-4$ & $2.989 E-4$ \\
\hline${ }^{232} \mathrm{Th}$ & - & - & - & $8.015 E+2$ & $8.012 E+2$ & $7.941 E+2$ & $1.519 E+3$ & $1.519 E+3$ & $1.507 E+3$ \\
\hline${ }^{233} \mathrm{Th}$ & - & - & - & - & $5.405 E-3$ & $5.611 E-3$ & - & $9.076 E-3$ & $9.442 E-3$ \\
\hline${ }^{233} \mathrm{~Pa}$ & - & - & - & - & $2.861 E-1$ & $4.904 E+0$ & - & $4.844 E-1$ & $8.354 E+0$ \\
\hline${ }^{233} \mathrm{U}$ & - & - & - & - & $4.488 E-3$ & $2.002 E+0$ & - & $7.619 E-3$ & $3.456 E+0$ \\
\hline${ }^{234} \mathrm{U}$ & - & $7.634 E-6$ & $8.355 E-4$ & - & $4.174 E-4$ & $2.331 E-1$ & - & $6.433 E-4$ & $3.748 E-1$ \\
\hline${ }^{235} \mathrm{U}$ & $3.120 E+2$ & $3.110 E+2$ & $2.807 E+2$ & $4.051 E+2$ & $4.034 E+2$ & $3.663 E+2$ & $4.372 E+2$ & $4.355 E+2$ & $3.978 E+2$ \\
\hline${ }^{236} \mathrm{U}$ & - & $2.194 E-1$ & $6.952 E+0$ & - & $3.892 E-1$ & $8.978 E+0$ & - & $3.954 E-1$ & $9.181 E+0$ \\
\hline${ }^{237} \mathrm{U}$ & - & $3.845 E-4$ & $5.459 E-2$ & - & $5.932 E-4$ & $6.547 E-2$ & - & $4.674 E-4$ & $6.445 E-2$ \\
\hline${ }^{238} \mathrm{U}$ & $3.276 E+3$ & $3.275 E+3$ & $3.252 E+3$ & $2.325 E+3$ & $2.324 E+3$ & $2.304 E+3$ & $1.525 E+3$ & $1.524 E+3$ & $1.509 E+3$ \\
\hline${ }^{239} \mathrm{U}$ & - & $2.151 E-2$ & $2.274 E-2$ & - & $1.574 E-2$ & $1.675 E-2$ & - & $1.175 E-2$ & $1.240 E-2$ \\
\hline${ }^{238} \mathrm{Pu}$ & - & - & $1.053 E-3$ & - & - & $1.629 E-3$ & - & - & $1.494 E-3$ \\
\hline${ }^{239} \mathrm{Pu}$ & - & $6.525 E-2$ & $1.768 E+1$ & - & $1.295 E-1$ & $1.615 E+1$ & - & $9.697 E-2$ & $1.224 E+1$ \\
\hline${ }^{240} \mathrm{Pu}$ & - & $7.266 E-4$ & $9.220 E-1$ & - & $1.359 E-3$ & $7.479 E-1$ & - & $9.769 E-4$ & $5.428 E-1$ \\
\hline${ }^{241} \mathrm{Pu}$ & - & - & $1.733 E-1$ & - & - & $1.435 E-1$ & - & - & $1.008 E-1$ \\
\hline Total & $3.588 E+3$ & $3.586 E+3$ & $3.559 E+3$ & $3.532 E+3$ & $3.529 E+3$ & $3.498 E+3$ & $3.481 E+3$ & $3.480 E+3$ & $3.448 E+3$ \\
\hline
\end{tabular}

${ }^{1}$ After 0.75 days $\left(k_{\text {eff }}=0.95\right) .{ }^{2}$ After 25 days $\left(k_{\text {eff }}=0.90\right)$.

${ }^{3}$ After 1.25 days $\left(k_{\text {eff }}=0.95\right) .{ }^{4}$ After 30 days $\left(k_{\text {eff }}=0.90\right)$.

${ }^{5}$ After 1.25 days $\left(k_{\text {eff }}=0.95\right) .{ }^{6}$ After 30 days $\left(k_{\text {eff }}=0.90\right)$.

(iii) A quasi-uniform fission power density profile is obtained for each fuel case $(\Gamma=1.021-1.029$ at the BOC).

(iv) Burn-up profiles increase quasi-linearly in all $P_{\mathrm{th}}$ 's with operation time. The highest value is $8.58 \mathrm{GWd} /$ MTU.

(v) Case 1(b) (including $\mathrm{ThO}_{2}$ and $15 \%$ enriched $\mathrm{UO}_{2}$ TRISO particles) is the best fuel case in terms of the energy gain $(G=148.64)$. (vi) ${ }^{233} \mathrm{U}$ and ${ }^{239} \mathrm{Pu}$ fissile fuels can be produced up to $155.1 \mathrm{~g}$ and $103.6 \mathrm{~g}$ per day, respectively.

In conclusion, the ADS flattened fission power density has a good neutronic performance in terms of effective utilizations of thorium and spent fuel and energy production. Furthermore, this work would light the way for obtaining a uniform fission power density profile for similar future works. 
TABLE 7: Masses of actinide isotopes [kgHM] at the beginning and at the end of the cycle (Case 2).

\begin{tabular}{lccc}
\hline Isotopes & BOC & EOC $^{1}$ & EOC $^{2}$ \\
\hline${ }^{231} \mathrm{Th}$ & - & $6.711 E-4$ & $6.574 E-4$ \\
${ }^{232} \mathrm{Th}$ & $2.468 E+3$ & $2.451 E+3$ & $2.374 E+3$ \\
${ }^{233} \mathrm{Th}$ & - & $1.231 E-2$ & $1.297 E-2$ \\
${ }^{233} \mathrm{~Pa}$ & - & $1.100 E+1$ & $1.995 E+1$ \\
${ }^{233} \mathrm{U}$ & - & $4.653 E+0$ & $5.359 E+1$ \\
${ }^{234} \mathrm{U}$ & - & $4.039 E-1$ & $5.973 E+0$ \\
${ }^{235} \mathrm{U}$ & - & $8.541 E-3$ & $6.315 E-1$ \\
${ }^{238} \mathrm{Pu}$ & $3.632 E+1$ & $3.520 E+1$ & $3.045 E+1$ \\
${ }^{239} \mathrm{Pu}$ & $4.644 E+2$ & $4.360 E+2$ & $3.256 E+2$ \\
${ }^{240} \mathrm{Pu}$ & $2.730 E+2$ & $2.696 E+2$ & $2.516 E+2$ \\
${ }^{241} \mathrm{Pu}$ & $1.661 E+2$ & $1.648 E+2$ & $1.535 E+2$ \\
${ }^{242} \mathrm{Pu}$ & $9.543 E+1$ & $9.525 E+1$ & $9.465 E+1$ \\
${ }^{243} \mathrm{Pu}$ & - & $3.420 E-2$ & $3.485 E-2$ \\
${ }^{244} \mathrm{Pu}$ & - & $7.213 E-4$ & $4.449 E-3$ \\
${ }^{241} \mathrm{Am}$ & - & $6.296 E-1$ & $2.790 E+0$ \\
${ }^{242} \mathrm{Am}$ & - & $1.944 E-3$ & $3.276 E-2$ \\
${ }^{243} \mathrm{Am}$ & - & $3.129 E+0$ & $1.345 E+1$ \\
${ }^{244} \mathrm{Am}$ & - & $4.735 E-3$ & $1.914 E-2$ \\
\hline${ }_{\mathrm{Total}}$ & $3.503 E+3$ & $3.472 E+3$ & $3.326 E+3$ \\
\hline${ }_{1} \mathrm{After} 30$ & & &
\end{tabular}

${ }^{1}$ After 30 days $\left(k_{\text {eff }}=0.95\right)$.

${ }^{2}$ After 165 days $\left(k_{\text {eff }}=0.90\right)$.

TABLE 8: Masses of actinide isotopes $[\mathrm{kgHM}]$ at the beginning and at the end of the cycle (Case 3).

\begin{tabular}{lccc}
\hline Isotopes & BOC & $\mathrm{EOC}^{1}$ & $\mathrm{EOC}^{2}$ \\
\hline${ }^{231} \mathrm{Th}$ & - & $4.644 E-4$ & $1.414 E-3$ \\
${ }^{232} \mathrm{Th}$ & $3.114 E+3$ & $3.113 E+3$ & $3.110 E+3$ \\
${ }^{233} \mathrm{Th}$ & - & $3.370 E-2$ & $3.608 E-2$ \\
${ }^{233} \mathrm{~Pa}$ & - & $7.145 E-1$ & $3.730 E+0$ \\
${ }^{233} \mathrm{U}$ & - & $4.390 E-3$ & $1.170 E-1$ \\
${ }^{234} \mathrm{U}$ & - & $7.117 E-4$ & $2.635 E-2$ \\
${ }^{235} \mathrm{U}$ & - & - & $1.304 E-4$ \\
${ }^{242} \mathrm{Cm}$ & $9.990 E+0$ & $9.961 E+0$ & $9.848 E+0$ \\
${ }^{243} \mathrm{Cm}$ & $1.210 E-1$ & $1.258 E-1$ & $1.453 E-1$ \\
${ }^{244} \mathrm{Cm}$ & $2.201 E+2$ & $2.198 E+2$ & $2.187 E+2$ \\
${ }^{245} \mathrm{Cm}$ & $2.465 E+1$ & $2.428 E+1$ & $2.284 E+1$ \\
${ }^{246} \mathrm{Cm}$ & $2.475 E+0$ & $2.553 E+0$ & $2.863 E+0$ \\
\hline Total & $3.371 E+3$ & $3.370 E+3$ & $3.368 E+3$ \\
\hline
\end{tabular}

${ }^{1}$ After 0.5 days $\left(k_{\text {eff }}=0.95\right) .{ }^{2}$ After 2.5 days $\left(k_{\text {eff }}=0.90\right)$.

\section{Competing Interests}

The authors declare that there are no competing interests regarding the publication of this paper.

\section{Acknowledgments}

This study is supported by the Research Fund of the Erciyes University, Project no. FDK-2015-5811.

\section{References}

[1] E. O. Lawrence, "AEC research and development report, facilities for electronuclear (MTA) program," Report LWS-24736, 1953.

[2] H. Yapıc1, N. Demir, and G. Genç, "Neutronic analysis for transmutation of minor actinides and long-lived fission products in a Fusion-Driven Transmuter (FDT)," Journal of Fusion Energy, vol. 25, no. 3-4, pp. 225-239, 2006.

[3] H. Yapıc1, G. Genç, and N. Demir, "Transmutation-incineration potential of transuraniums discharged from PWR- $\mathrm{UO}_{2}$ spent fuel in modified PROMETHEUS fusion reactor," Fusion Engineering and Design, vol. 81, no. 18, pp. 2093-2108, 2006.

[4] G. P. Barros, C. Pereira, M. A. F. Veloso, and A. L. Costa, "Thorium and reprocessed fuel utilization in an acceleratordriven system," Annals of Nuclear Energy, vol. 80, pp. 14-20, 2015.

[5] G. D. P. Barros, C. Pereira, M. A. F. Veloso, and A. L. Costa, "Study of an ADS loaded with thorium and reprocessed fuel," Science and Technology of Nuclear Installations, vol. 2012, Article ID 934105, 12 pages, 2012.

[6] T. M. Vu and T. Kitada, "Transmutation strategy using thoriumreprocessed fuel ADS for future reactors in Vietnam," Science and Technology of Nuclear Installations, vol. 2013, Article ID 674638, 5 pages, 2013.

[7] A. Abánades and A. Pérez-Navarro, "Engineering design studies for the transmutation of nuclear wastes with a gas-cooled pebble-bed ADS," Nuclear Engineering and Design, vol. 237, no. 3, pp. 325-333, 2007.

[8] L. García, J. Pérez, C. García, A. Escrivá, J. Rosales, and A. Abánades, "Calculation of the packing fraction in a pebble-bed ADS and redesigning of the Transmutation Advanced Device for Sustainable Energy Applications (TADSEA)," Nuclear Engineering and Design, vol. 253, pp. 142-152, 2012.

[9] T. Takizuka, K. Tsujimoto, T. Sasa, K. Nishihara, and H. Takano, "Design study of lead-bismuth cooled ADS dedicated to nuclear waste transmutation," Progress in Nuclear Energy, vol. 40, no. 34, pp. 505-512, 2002.

[10] K. Tsujimoto, T. Sasa, K. Nishihara, H. Oigawa, and H. Takano, "Neutronics design for lead-bismuth cooled accelerator-driven system for transmutation of minor actinide," Journal of Nuclear Science and Technology, vol. 41, no. 1, pp. 21-36, 2004.

[11] K. Ismailov, M. Saito, H. Sagara, and K. Nishihara, "Feasibility of uranium spallation target in accelerator-driven system," Progress in Nuclear Energy, vol. 53, no. 7, pp. 925-929, 2011.

[12] Y. Malyshkin, I. Pshenichnov, I. Mishustin, and W. Greiner, "Monte Carlo modeling of spallation targets containing uranium and americium," Nuclear Instruments and Methods in Physics Research, Section B: Beam Interactions with Materials and Atoms, vol. 334, pp. 8-17, 2014.

[13] H. Yapıc1, G. Genç, and N. Demïr, "Neutronic limits in infinite target mediums driven by high energetic protons," Annals of Nuclear Energy, vol. 34, no. 5, pp. 374-384, 2007.

[14] H. Yapıc1, G. Genç, and N. Demir, "A comprehensive study on neutronics of a lead-bismuth eutectic cooled accelerator-driven sub-critical system for long-lived fission product transmutation," Annals of Nuclear Energy, vol. 35, no. 7, pp. 1264-1273, 2008.

[15] G. Bakır, B. S. Selçuklu, G. Genç, and H. Yapıcı, "Neutronic analysis of LBE-uranium spallation target accelerator driven system loaded with uranium dioxide in TRISO particles," Acta Physica Polonica A, vol. 129, no. 1, pp. 30-32, 2016. 
[16] A. H. Martínez, Y. Kadi, and G. Parks, "Transmutation of nuclear waste in accelerator-driven systems: thermal spectrum," Annals of Nuclear Energy, vol. 34, no. 7, pp. 550-563, 2007.

[17] J. Adam, K. Katovský, A. Balabekyan et al., "Transmutation of ${ }^{129} \mathrm{I},{ }^{237} \mathrm{~Np},{ }^{238} \mathrm{Pu},{ }^{239} \mathrm{Pu}$, and ${ }^{241} \mathrm{Am}$ using neutrons produced in target-blanket system 'Energy plus Transmutation' by relativistic protons," Pramana, vol. 68, no. 2, pp. 201-212, 2007.

[18] V. Artisyuk, A. Chmelev, M. Saito, M. Suzuki, and Y. Fujii-E, “ ${ }^{244} \mathrm{Cm}$ transmutation in accelerator-driven system," Journal of Nuclear Science and Technology, vol. 36, no. 12, pp. 1135-1140, 1999.

[19] Á. Brolly and P. Vértes, "Concept of a small-scale electron accelerator driven system for nuclear waste transmutation: part 2. Investigation of burnup," Annals of Nuclear Energy, vol. 32, no. 4, pp. 417-433, 2005.

[20] W. Haeck, E. Malambu, V. P. Sobolev, and H. Ait Abderrahim, "Assessment of americium and curium transmutation in magnesia based targets in different spectral zones of an experimental accelerator driven system," Journal of Nuclear Materials, vol. 352, no. 1-3, pp. 285-290, 2006.

[21] T. Mukaiyama, H. Takano, T. Ogawa, T. Takizuka, and M. Mizumoto, "Partitioning and transmutation studies at JAERI both under OMEGA program and high-intensity proton accelerator project," Progress in Nuclear Energy, vol. 40, no. 3-4, pp. 403-413, 2002.

[22] W. S. Park, T. Y. Song, B. O. Lee, and C. K. Park, "A preliminary design study for the HYPER system," Nuclear Engineering and Design, vol. 219, no. 3, pp. 207-223, 2003.

[23] P. Seltborg and J. Wallenius, "Proton source efficiency for heterogeneous distribution of actinides in the core of an accelerator-driven system," Nuclear Science and Engineering, vol. 154, no. 2, pp. 202-214, 2006.

[24] K. Tsujimoto, T. Sasa, K. Nishihara, T. Takizuka, and H. Takano, "Accelerator-driven system for transmutation of highlevel waste," Progress in Nuclear Energy, vol. 37, no. 1-4, pp. 339344, 2000.

[25] D. C. Wade, W. S. Yang, and H. Khalil, "ATW neutronics design studies," Progress in Nuclear Energy, vol. 40, no. 3-4, pp. 497504, 2002.

[26] J. Wallenius and M. Eriksson, "Neutronics of minor-actinide burning accelerator-driven systems with ceramic fuel," Nuclear Technology, vol. 152, no. 3, pp. 367-381, 2005.

[27] D. Westlén and J. Wallenius, "Neutronic and safety aspects of a gas-cooled subcritical core for minor actinide transmutation," Nuclear Technology, vol. 154, no. 1, pp. 41-51, 2006.

[28] H. Yapıc1 and M. Übeyli, "Power flattening in Prometheus breeder reactor using nuclear fuel and waste actinide," Annals of Nuclear Energy, vol. 30, no. 2, pp. 159-173, 2003.

[29] H. Yapic1, "Power flattening of an inertial fusion energy breeder with mixed $\mathrm{ThO}_{2}-\mathrm{UO}_{2}$ fuel," Fusion Engineering and Design, vol. 65 , no. 1, pp. 89-108, 2003.

[30] G. Bakır, S. B. Selçuklu, and H. Yapıcı, "Medical radioisotope production in a power-flattened ADS fuelled with uranium and plutonium dioxides," Science and Technology of Nuclear Installations, vol. 2016, Article ID 5302176, 11 pages, 2016.

[31] H.-C. Kim, S. Y. Kim, J. K. Kim, and J. M. Noh, "Monte Carlo benchmark calculations for 400MWth PBMR core," in Proceedings of the 13th International Conference on Emerging Nuclear Energy Systems (ICENES '07), pp. 498-502, Istanbul, Turkey, June 2007.

[32] B. Manson, H. P. Thomas, and W. L. Hans, Nuclear Chemical Engineering, McGraw-Hill, New York, NY, USA, 1981.
[33] S. T. Mongelli, J. R. Maiorino, S. Anéfalos, A. Deppman, and T. Carluccio, "Spallation physics and the ADS target design," Brazilian Journal of Physics, vol. 35, no. 3, pp. 894-897, 2005.

[34] J. H. Conway and N. J. A. Sloane, Sphere-Packings, Lattices and Groups, Springer, New York, NY, USA, 3rd edition, 1999.

[35] D. B. Pelowitz, “MCNPX, user's manual, version 2.6.0," Tech. Rep. LA-CP-07-1473, Los Alamos National Laboratory, 2008.

[36] M. B. Chadwick, P. G. Young, S. Chiba et al., "Cross-section evaluations to $150 \mathrm{MeV}$ for accelerator-driven systems and implementation in MCNPX," Nuclear Science and Engineering, vol. 131, no. 2-3, pp. 293-328, 1999.

[37] H. W. Bertini, "Low-energy intranuclear cascade calculation," Physical Review, vol. 131, no. 4, p. 1801, 1963. 

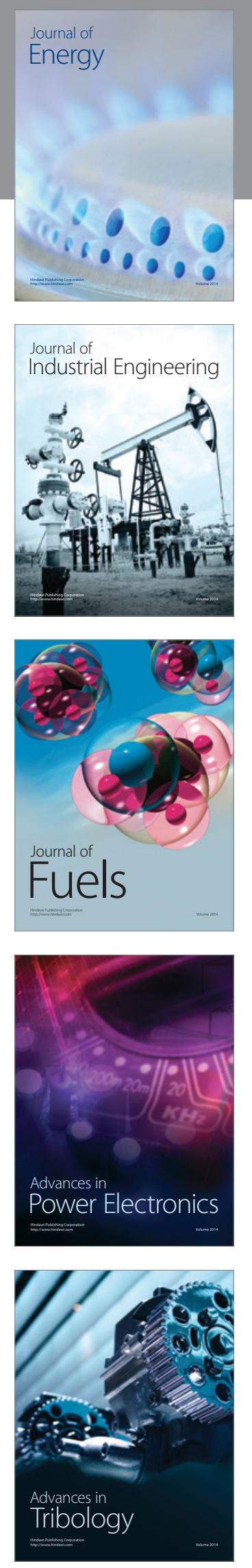
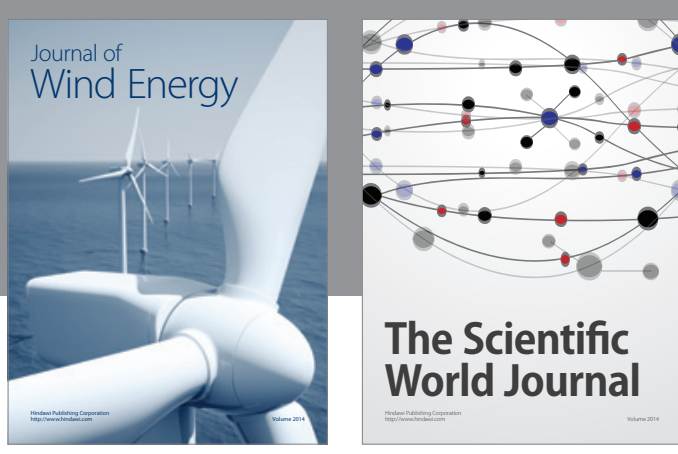

The Scientific World Journal
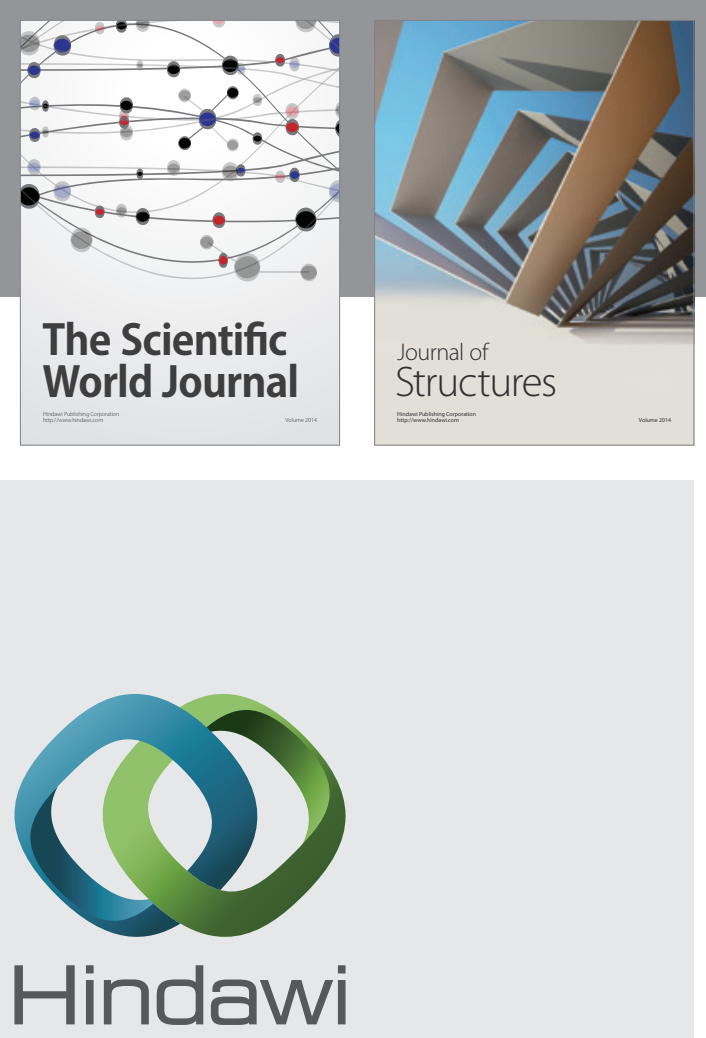

Submit your manuscripts at

http://www.hindawi.com
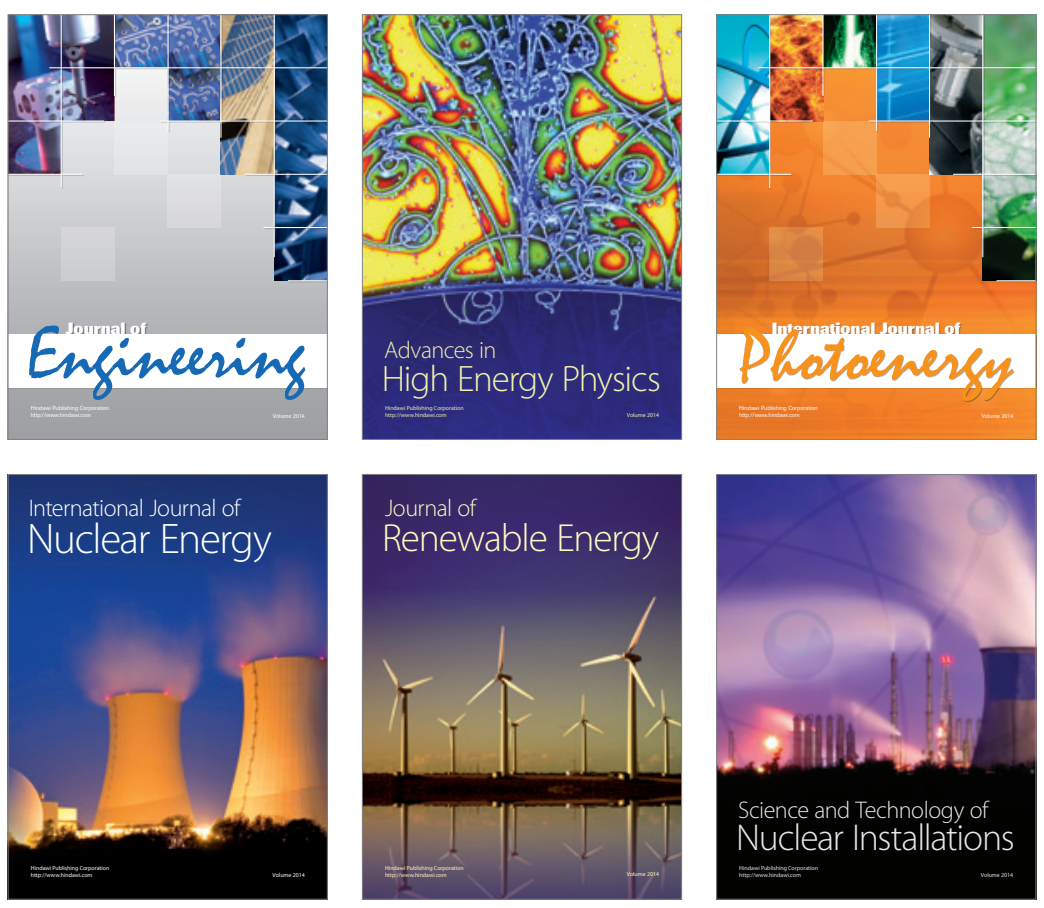
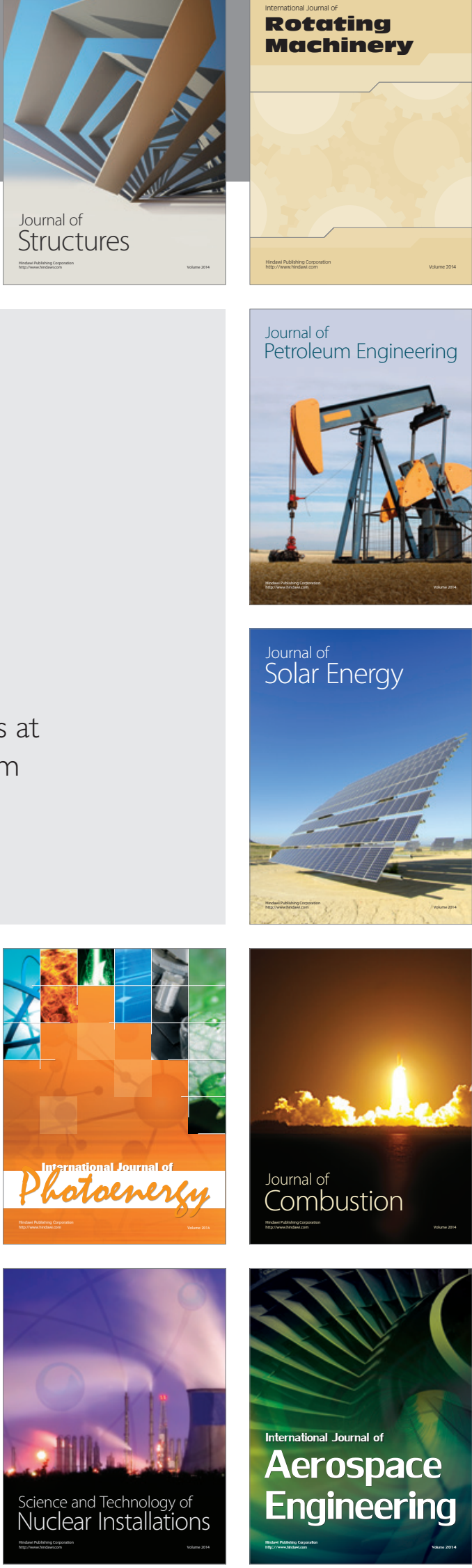